\title{
ÉTICA E VERGONHA NA CARA ${ }^{1}$
}

\author{
CAETANO, Vitor Nunes ${ }^{2}$
}

Ética e vergonha na cara. Este é o titulo do livro escrito pelos professores Mario Sergio Cortella e Clóvis de Barros Filho. Produzido a partir do registro de um envolvente diálogo entre os dois, lembrando em muito aquela conhecida brincadeira de altinho feita pelos jogadores de futebol. A bola, digo, o tema, rola de um para o outro, em passes que se complementam, isto feito de forma leve, porém bastante substancial. É dessa forma que nos são reveladas as nuances que devemos considerar quando nos propomos discutir o assunto ética.

Com o intuito de cumprir o objetivo didático, de melhor guiar o leitor pela roteirização utilizada pelos autores, no curso dessa conversa, o livro foi dividido em dez tópicos e mais um glossário, sendo eles: "A ética da conveniência", "A ilusão moral do foco no resultado", "Qual é o resultado que torna justo caminho?", "Ética como instrução", "Não há vida sem escolha, e não há escolha sem valor", "Corrupção: Consequência do sistema?", "Uma questão de escolha", "A corrupção e o sistema político", "A corrupção e a família" e "É vergonhoso não ser querido".

Nesses tópicos, Cortella e Barros Filho nos arrastam para uma irresistível reflexão sobre ética, começando pelo espinhoso tema da corrupção, que é tratado pelos autores, à luz da questão do relativismo moral e da ética da conveniência, tão próprios para a nossa época. Para isto, ambos lançam mão de situações exemplares, baseadas também em fatos contemporâneos, dialogando com referenciais da ordem de Platão, Sócrates, Espinosa, Kant Morin, entre outros, que ajudam a colocar em xeque quaisquer certezas que talvez tenhamos sobre o significado do bem agir de nossas condutas, mostrando a complexidade que envolve as situações que se apresentam para nossa avaliação. Para isso, Cortella e Barros Filho dialogam sobre a lógica do resultado, da meta e do sucesso e a forma como os procedimentos e os meios são tornados menores, frente aos objetivos que desejamos atingir.

0 conceito de ética, discutido aqui pelos autores, é aquele pautado por um conjunto de princípios e valores, que podemos usar como guia de nossas condutas, mas não como uma tabela onde pretensamente se separe o certo do errado de forma absoluta, mas sim proposições, que uma vez discutidas e acordadas por aqueles que convivem, nos possibilitem rechaçar escolhas que possam manchar o sentido daquilo que consideremos o bem agir.

Com os autores, aprendemos, portanto, a reconhecer a vergonha, um dos aspectos da ética, como um tipo especial de tristeza, um afeto que surge quando a causa é flagrada em nós, originada em nossa própria conduta. A ética, situando a forma como agimos, deve colocar na nossa cara as consequências dos nossos atos. Sendo assim, ela deve se configurar, cada vez mais, como uma disposição para deliberarmos em conjunto, aquilo que possamos cultivar de melhor para o aperfeiçoamento da convivência humana.

\footnotetext{
${ }^{1}$ Ética e vergonha na cara! CORTELLA, M. S, BARROS FILHO, C. - Campinas, SP: Papirus 7 Mares, 2014.

2 Mestrando do PPGEB-CAp UERJ, Esp. Informática Aplicada a Educação - FTE Souza Marques, Esp. Mídias na Educação - UFRJ, Prof. I E.M Mozart Lago / 5aCRE/SMERJ, Prof. Articulador Pedagógico CE Prof. Ernesto Faria / SEEDUC - RJ. vitornca@globo.com
} 